\title{
KANAPIŲ IR ABRIKOSŲ ALIEJŲ PAGRINDU PAGAMINTŲ EMULSIJŲ POVEIKIS DEHIDRATUOTAI RANKŲ ODAI
}

\author{
Diana Barragan Ferrer ${ }^{1}$, Žaneta Mickieneㄹ ${ }^{1}$, Jesus Manuel Barragan Ferrer ${ }^{1}$, \\ Aurika Jančiauskaite் ${ }^{1}$, Audronė Klimavičiené ${ }^{1}$, Sandrija Čapkauskiene் ${ }^{1,2}$ \\ ${ }^{1}$ Kauno kolegijos Medicinos fakultetas, ${ }^{2}$ Lietuvos sporto universiteto \\ Taikomosios reabilitacijos ir biologijos katedra
}

Raktažodžiai: dehidratuota rankų oda, emulsija, kanapių sẻklų aliejus, abrikosų kauliukų aliejus.

\begin{abstract}
Santrauka
Epidermio dehidratacija tampa viena iš dažniausiai vyraujančių odos problemų. Dehidratuotos odos pralaidumas yra padidèjęs, todèl ị gilesnius odos sluoksnius iš kosmetikos produktų patenka ir kenksmingos, dirginančios medžiagos, kas gali sukelti dar rimtesnius odos būklès pažeidimus bei ligas. Pasireiškus dehidratuotos odos požymiams siekiama pirmuosius simptomus sumažinti naudojant kosmetines priemones, kurios ne visada padeda spręsti problemas. Per pastaruosius metus ypač išaugo natūralios kosmetikos gamyba, daug dèmesio skiriama natūraliems augaliniams aliejams. Emulsijos, kurių pagrindą sudaro augaliniai aliejai, ypač kanapių, abrikosų, dèl didelio kiekio nesočiujų riebalų rūgščių bei kitų juose esančiu aktyvių komponentų gali atstatyti odos barjerą, kas sąlygotų pakankamą vandens kiekio išlaikymą odoje bei mažesni kosmetikos produktų vartojimo kiekị siekiant išspręsti dehidratacijos sukeltus simptomus. Naudodami tokias natūralias emulsijas dehidratuotai odai sumažintume kenksmingų medžiagų patekimą i organizmą. Natūralios kosmetikos gamintojai emulsijų gamybai naudoja įvairius natūralius augalinius aliejus, tokius kaip kokoso, saulègrąžų, migdolų, makadamijos riešutų ir kt.

Tyrimo tikslas - nustatyti, koks yra kanapių sèklų ir abrikosų kauliukų aliejų pagrindu pagamintų emulsijų poveikis dehidratuotai rankų odai. Tyrimo rezultatai parodè, kad dehidratuotą rankų odą efektyviau atstato emulsija su kanapių sėklų aliejumi nei su abrikosų kauliukų aliejumi.
\end{abstract}

\section{Ivadas}

Pakankamas drègmès kiekis odoje yra būtinas, kad ląstelès galètų normaliai funkcionuoti [1]. Odos hidrobalanso pa- laikymui svarbiausias yra odos viršutinis epidermio sluoksnis. Jis užtikrina barjerą nuo vandens netekimo iš gilesnių odos sluoksnių [2].

Oda yra didžiausias kūno organas, svarbus ne tik tuo, kad formuoja žmogaus išvaizdą, bet ir yra pagrindinis apsauginis barjeras tarp kūno vidinès terpès ir aplinkoje veikiančių faktorių. Apsaugą formuoja du pagrindiniai barjerai: hidrolipidinè mantija ir epidermio raginis sluoksnis- negyvų ląstelių ir lipidų kompleksas [3]. Barjero komponentų trūkumas tiesiogiai sąlygoja vandens netekimą odoje, jo trūkumas sutrikdo normalų ląstelių funkcionavimą [4]. Odos dehidratacija tampa viena iš dažniausiai vyraujančių odos problemų [5]. Pasireiškus dehidratuotos odos požymiams, žmonès viršija kosmetinių priemonių kiekius ar naudoja netinkamą kosmetiką problemai spręsti [4]. Tokios odos pralaidumas yra padideję̨s, todèl ị gilesnius jos sluoksnius iš kosmetikos produktų patenka ir dirginančios medžiagos, kas gali sukelti dar rimtesnius odos būklès pažeidimus ar ligas [3,6]. J.Liesienè ir kt. teigia, kad per pastaruosius metus ypač išaugo susidomejjimas augaliniais aliejais [7]. Augalinių aliejų sudètyje yra daug nesočiųjų riebalų rūgščių, kurios yra analogiškos odos barjero lipidų struktūrai. Kremai ar emulsijos, kurių pagrindą sudaro augaliniai aliejai, ypač kanapių sėklų ar abrikosų kauliukų aliejus, dèl didelio kiekio šių rūgščių bei kitų juose esančių aktyvių komponentų gali atstatyti odos barjerą, o tai sąlygotų pakankamą vandens kiekio išlaikymą odoje [8-9].

Visose kanapių sèklose yra maždaug 25\% baltymų, 31\% riebalų, 34\% angliavandenių bei vitaminų ir mineralų [10]. Dèl maistinès vertès ir gydomųjų savybių kanapių sẻklos ir jų aliejus jau seniai buvo pripažintas Azijoje, Indijoje, Rusijoje ir Rytų Europoje [11].

Kanapių sėklų aliejus (kanapių aliejus) laikomas vienas vertingiausių augalinių aliejų dẻ jo sudètyje esančių dviejų polinesočiujų riebalų rūgščių: linolo rūgšties ir gama - linoleno rūgšties, iš omega -6 šeimos ir $\alpha$-linoleno rūgšties, 
iš omega -3 šeimos [12]. Dẻl didelio šių rūgščių kiekio (iki $84 \%$ ) kanapių aliejus dar vadinamas - nepakeičiamujų nesočiujų riebiujų rūgščių (NNRR) mišiniu [13].

Aliejuje taip pat yra ir alfa linoleno rūgšties metabolitas- stearidono rūgštis. Sočiujjų riebalų: stearino, palimtino rūgščiu kiekis aliejuje neviršija 5\% [14]. Kanapių aliejuje taip pat yra vitaminų A, C, E, B2, B3, B6, mikroelementų (kalcio, magnio, kalio, geležies, cinko), chlorofilo [15]. Nesočiosios riebalų rūgštys įeina ị drèkinamujų kremų sudètį, skatina epiderminio barjero atsistatymą. Sočiosios riebalų rūgštys įdedamos į maitinamujų kremų emulsijų sudètis, jų koncentracija lemia, kokiam odos tipui bus naudojamas kosmetikos gaminys. Kanapių aliejuje didžiausią dalį sudaro drèkinančią funkciją atliekančios NNRR, iš jų dvi pagrindinès: linoleno ir alfa-linoleno rūgštys [16]. Kanapių aliejaus kiekio naudojimas konkrečiuose kosmetikos produktuose skiriasi. Masažiniuose produktuose, lūpų balzamuose aliejaus koncentracija gali siekti iki 75 procentų. Yra manančių, kad gryną kanapių aliejų be jokių priemaišų taip pat galima naudoti ant odos kosmetinių procedūrų metu. Tačiau, J.Liang teigia, kad gryna aliejaus konsistencija dèl didelio kiekio žalio pigmento (chlorofilo) ant odos greitai oksiduojasi, gali sukelti nemalonų kvapą [14]. Rekomenduotinas aliejaus kiekis reguliariai vartojamuose nenuplaunamuose, drèkinančiuose kosmetikos produktuose turètų būti iki $10 \%$ [12].

Abrikosų sėklų aliejus turi didelị kiekị mononesočiosios oleino rūgšties $60-70,9 \%$. Sudetyje linolo rūgšties yra apie $20-30 \%$, aliejuje mažai sočiujų riebalų rūgščių, tokių kaip palmitino rūgštis 4,0-4,5\% ir stearino rūgšties $1-1,24 \%$. Taip pat randama nedideli kiekiai kitų riebalų rūgščių: linoleno rūgšties $(0,08-0,13 \%)$, arachidono rūgšties $(0,10-0,12 \%)$ ir eikozeno rūgšties $(0,11 \%)$ [17]. Aliejus naudojamas daugelio kosmetikos gamybos produktuose: drèkinamuosiuose kremuose sausoms odoms, kūdikių aliejuose, masažiniuose aliejuose, veido šveitikliuose, lūpų balzamuose, plaukų priemonèse [18]. Aliejus naudingas kaip minkštiklis, nes jis turi „slydimo“ savybę. Ši savybė leidžia aliejui veikti kaip drèkinančiam agentui, užkertant kelią per dideliam drègmès

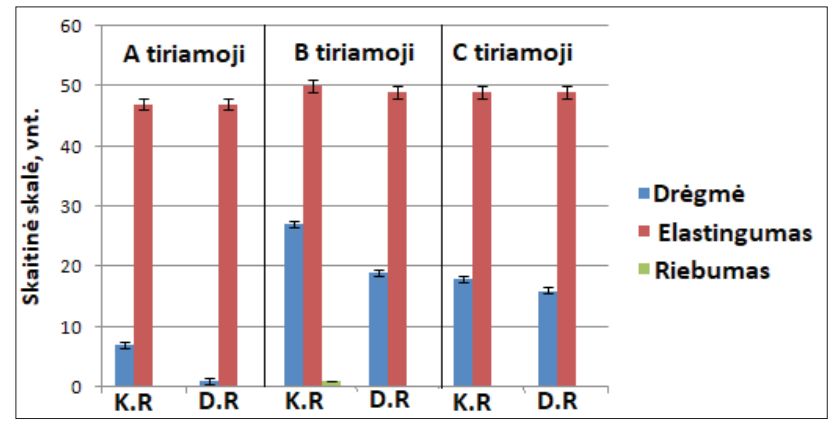

1 pav. Pradiniai tiriamujų rankų odos diagnostikos duomenys $(n=3)$. praradimui per epidermi [18]. Aliejus lengvai įsiskverbia ị odą, nepalieka riebios liekanos. L.Małgorzata ir kt. teigia, kad $84 \%$ iš 23 respondentų po abrikosų aliejaus vartojimo ant odos jo absorbciją ịvertino „gerai“ arba „labai gerai“ [19]. Jis taip pat naudojamas masažui ir kaip bazè su kitais aromaterapiniais aliejais. Jị toleruoja net ir riešutams alergiją turintys žmonès. Turi priešuždegiminių, antibakterinių, antiseptinių savybių. Tai vienas stabiliausių aliejų.

Tyrimo tikslas - nustatyti kanapių ir abrikosų aliejų pagrindu pagamintų emulsijų poveikį dehidratuotai rankų odai.

\section{Tyrimo objektas ir metodika}

Tyrime dalyvavo penkios 20-25 metų moterys, kurios buvo suskirstytos ị dvi grupes:

I. 3 (trys) moterys sudare eksperimentinę tiriamają grupę; II. 2 (dvi) moterys sudare kontrolinę tiriamają grupę.

Pasirinktos 20-25 metų moterys, nes šio amžiaus tarpsniu dar nevyksta senėjimo procesai, galintys veikti rankų odos drégmès kiekį. O dažniausia dehidratuotos rankų odos būklès priežastimi laikoma netinkama priežiūra.

Tiriamujų plaštakų odos būklẻ buvo ịvertinta „Skin Analyzer Soft Plus“ diagnostikos aparatu, „Hands“ programa. Odos diagnostika buvo atliekama prieš tyrimą, eksperimento metu kartą per savaitę ir eksperimento pabaigoje, praejus 1-2 savaitèms po emulsijų naudojimo. Tyrimo metu buvo matuojama drègmé, riebumas ir elastingumas. Visi trys parametrai vertinami abiejų rankų. Diagnostikos dieną kosmetinių priemonių ant rankų odos tiriamosios nenaudojo. Tyrimo trukmé 1,5 mén. Tyrimui naudotos dvi emulsijos, viena ant vienos rankos kita ant kitos ir vertinta augalinio aliejaus įtaka dehidratuotai rankų odai. Emulsijų sudètis: damaskinių rožių vanduo (Damask Rose Water), kanapių arba abrikosų aliejus (Cannabis sativa hemp seed oil / Prunus armeniaca kernel oil), emulsinis vaškas (Glyceryl Stearate), greipfrutų sèklu ekstraktas (Citrus grandis seed extract). Emulsijos skyrèsi

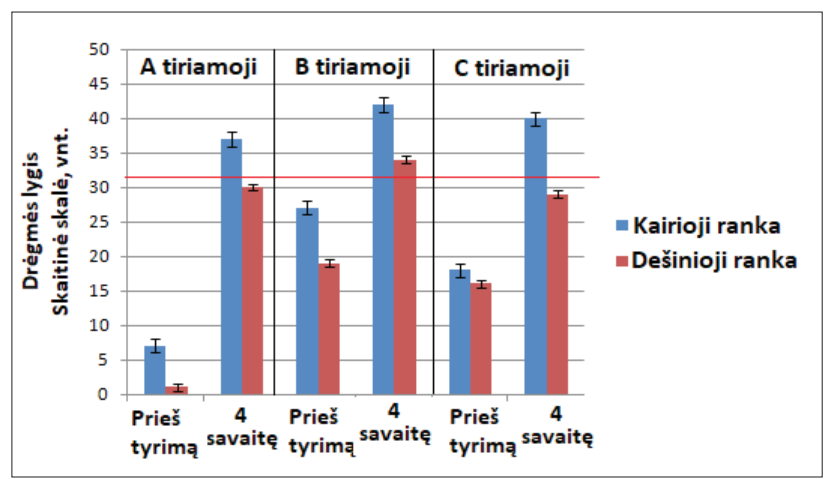

2 pav. Drègmès kiekis prieš ir paskutinę tyrimo savaitę $(n=3)$ (Horizontali linija rodo ribą tarp dehidratuotos ir normalios odos būklès). 
tik augaliniu aliejumi. Tiriamosios turèjo naudoti emulsiją du kartus per dieną (ryte ir vakare). Kanapių aliejaus pagrindu pagamintą emulsiją tiriamosios naudojo ant kairiosios, o abrikosų aliejaus pagrindu pagamintą emulsiją ant dešiniosios plaštakų. O kontrolinė grupė naudojo emulsijas atvirkščiai, t.y ant kairiosios plaštakos tepama abrikosų aliejaus pagrindu pagaminta emulsija, o ant dešinès kanapių aliejaus pagrindu pagaminta emulsija. Kaip pagalbinè priemonè, neleidžianti susimaišyti skirtingoms emulsijoms ant odos, buvo naudojamos vienkartinès pirštinès, prieš ištepant ranką su analizuojama emulsija. Visos tiriamosios emulsijas su kanapių ir abrikosų aliejais naudojo vienodą laiko intervalą - 4 savaites, po jų dvi savaites buvo stebimas išliekamasis poveikis kai emulsijos netepamos.

\section{Tyrimo rezultatai}

Emulsijų poveikis eksperimentinès grupès rankų odai. Prieš tyrimą buvo nustatyti pradiniai rankų odos būklès duomenys (1 pav.). Pradiniams rezultatams ịvertinti buvo remtasi diagnostikos aparato nurodytomis skaitinemmis vertemis (sąlyginiais skaitiniais vienetais).

Nustatyta, kad A tiriamosios abiejų plaštakų odos būklè yra labai dehidratuota (skaitine drègmès vertè -1-7). B ir C tiriamujjų abiejų rankų odos būklè priskiriama dehidratuotai

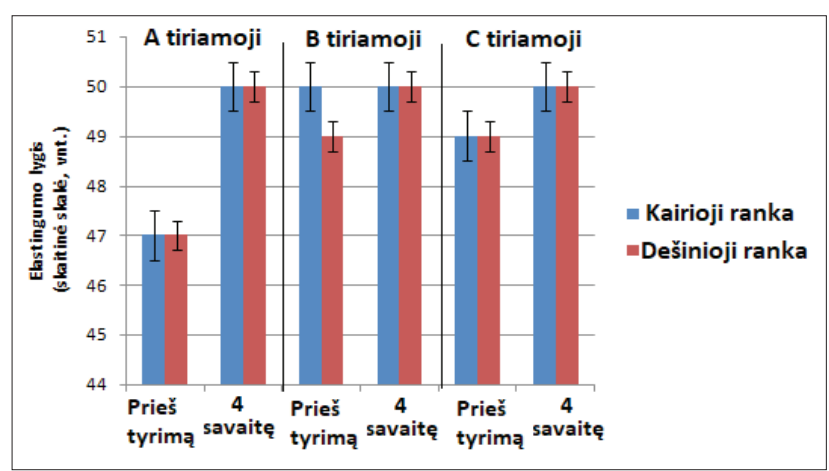

3 pav. Elastingumo lygis prieš ir paskutinę tyrimo savaitę $(n=3)$.

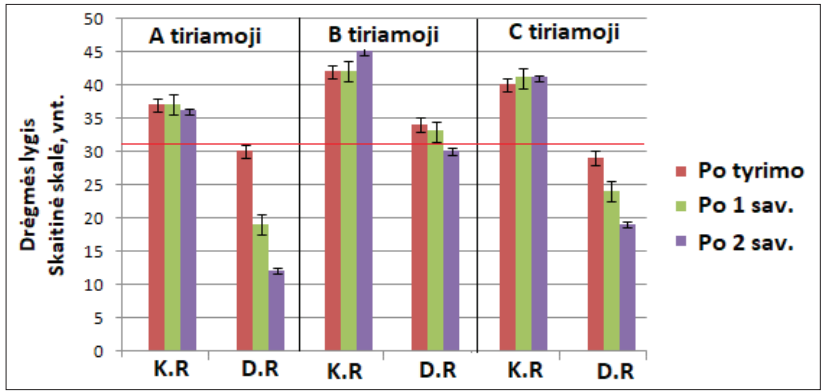

4 pav. Išliekamasis emulsijos poveikis (rankų odos drégmès pokytis $(\mathrm{n}=3)$. K.R-kairioji ranka; D.R- dešinioji ranka). (skaitinè vertė - 16-27). Visų trijų tiriamujų rankų odos riebumas buvo $0-1$ sąlyginis matavimo vienetas ir fiksuojama kaip sausa oda. Elastingumo faktorius laikomas (47-50) normalus (geras) tokiai amžiaus grupei. Diagramoje pateiktais duomenimis, didesnis dehidratacijos lygis nustatytas dešiniosios rankos. Visos tiriamosios yra dešiniarankès, todèl dešiniajai rankai tikriausiai tenka didesnè darbo apkrova, todèl ji yra stipriau veikiama išorinių veiksnių.

Eksperimento metu naudota emulsija su kanapių ir abrikosų aliejais turejo reikšmès tiek dešiniosios, tiek kairiosios rankų drègmès pokyčiams ( 2 pav.). Remdamiesi tyrimo duomenimis, galime teigti, kad kairiųų plaštakų, ant kurių buvo tepama emulsija su kanapių aliejumi, odos drègmès lygis iki normalaus atsistatè visų trijų tiriamujų (padidèjo apie 2 -5 karto nuo pradinio matavimo). Dešiniujų plaštakų odos vandens lygis iki normalaus atsistate tik vienos (B) tiriamosios, kitų tiriamųjų drègmès lygis odoje pakilo, tačiau nepakankamai ir oda liko dehidratuotos būklès.

Nepakankamą dešiniujų plaštakų odos drègmès kiekio kilimą, naudojant emulsiją su abrikosų kauliukų branduolių aliejumi, galëjo paveikti ženkliai dehidratuota rankų oda su pažeista barjerine funkcija. Plaštakų odai būdinga specifinè anatominè sandara, minimalus poodinio riebalinio audinio storis, daug prakaito ir mažai riebalinių liaukų, todèl ji yra

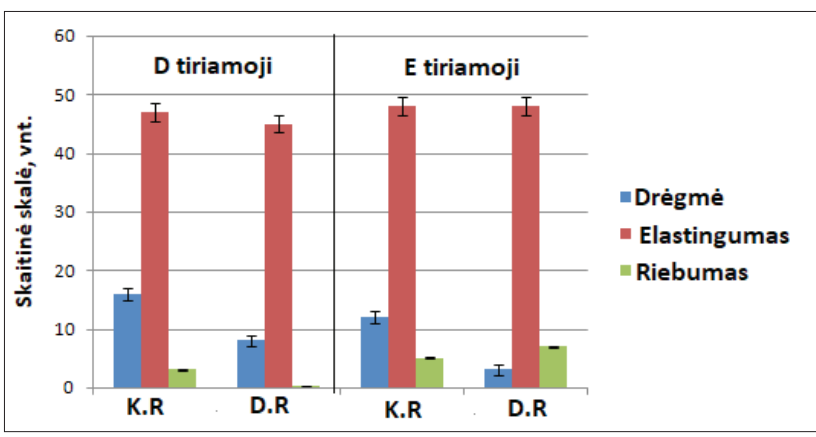

5 pav. Pradiniai kontrolinès grupès rankų odos diagnostikos duomenys $(n=2)$.

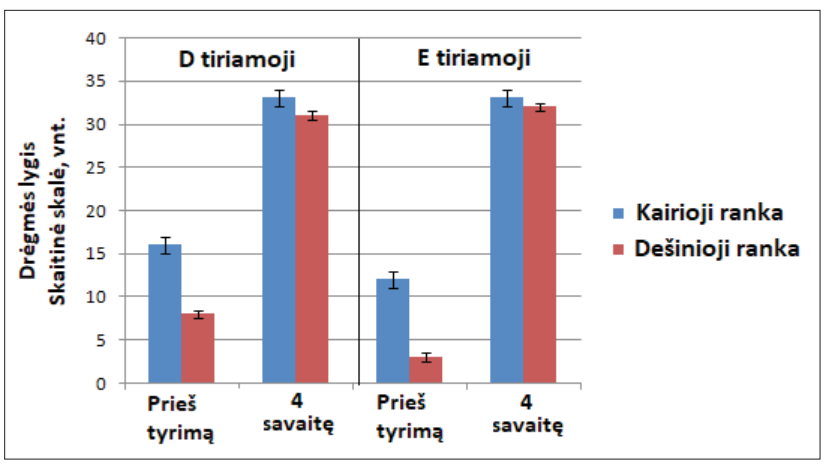

6 pav. Drègmès lygis prieš ir paskutinę tyrimo savaitę $(n=2)$. 
plonesnè, sausesnè ir pažeidžiamesnè [3].

Riebumas ant tiriamụjų dešiniujų plaštakų odos buvo lygus 0 sąlyginių vienetų, reiškiančių sausą odos tipą. Ketvirtą tyrimo savaitę nustatytas padidejęs riebumo kiekis (3-7 sąlyginių vienetu). Ant kairiosios plaštakos riebumo lygis eksperimento metu taip pat užfiksuotas didesnis, nei buvo prieš tyrimą.

Emulsijų naudojimas turejo poveikị dešiniosios ir kairiosios rankos elastingumui ( 3 pav.). Remdamiesi gautais matavimų duomenimis, galime teigti, kad visų tiriamųų plaštakų odos elastingumas pagerèjo iki maksimalios ribos, t.y. iki 50 sąlyginių vienetų. Elastingumo parametro didejjimą lèmè odos drègmès kilimas.

Išliekamasis emulsijų poveikis drègmès parametrui. Po keturių tyrimo savaičių kai visų trijų tiriamujjų kairiujjų plaštakų odos drègmè buvo atkurta iki normalios, buvo nustatytas išliekamasis poveikis. Išliekamasis emulsijos poveikis su kanapių séklų aliejumi buvo nustatytas du kartus - kas savaitę. Šias dvi savaites tiriamosios nenaudojo jokių kosmetinių priemonių, skirtų rankų odai. Tiek pirmą, tiek antrą savaitę išliekamasis hidratacijos lygis pakito neženkliai (4 pav.).

Iš gautų rezultatų galima teigti, kad emulsija su kanapių aliejumi efektyviau atstatinèjo dehidratuotą rankų odos būklę. Buvo atkurta barjerinè epidermio funkcija, todèl atstatyta odos pusiausvyra tarp vandens prisijungimo ir jo atidavimo $i$ aplinką. Drègmès lygio nesumažèjimui turi ịtakos ir tai, kad tiriamosios per šias 2 savaites naudojo apsaugines priemones (pirštines), todèl oda buvo mažiau veikiama neigiamų išorinių faktorių.

Emulsijų poveikis kontrolinės grupės rankų odai. Norint išsiaiškinti, ar emulsija su kanapių aliejumi gali efektyviau atkurti dehidratuotą rankų odos būklę, buvo sudaryta kontrolinè grupè. Ją sudarè 2 tiriamosios, kurios eksperimento metu emulsiją su abrikosų aliejumi naudojo ant kairiosios rankos, o su kanapių aliejumi - ant dešiniosios rankos.

Atlikus pradinę diagnostiką (5 Pav.) nustatyta, kad tiriamųjų rankos yra labai dehidratuotos būklès: kairiosios drègmès lygis siekia 12-16, o dešiniosios - 3-8 sąlyginiai vienetai. Riebumo lygis ant plaštakų odos paviršiaus žemas, 0-7 sąlyginiai vienetai. Mažesnis elastingumas nustatytas ant dešiniosios D tiriamosios rankos. E tiriamosios plaštakų odos elastingumas vienodas (48 sąlyginiai vienetai). Tiriamosios emulsiją naudoja tokị pat laiko tarpą kaip ir eksperimentinè grupè.

Eksperimento metu kontrolinei grupei rankų drègmès lygis pakilo iki normalaus (31 sąlyginio vieneto ir daugiau). Galime teigti, kad kairiosios rankos, kurios buvo tepamos emulsija su abrikosų aliejumi, ir dešiniosios, kurios buvo tepamos emulsija su kanapių aliejumi, drègmès lygis atsistatė panašiu santykiu, 31-33:32-33. (6 pav.). Išliekamasis poveikis po dviejų savaičių buvo fiksuojamas ir nustatyta, kad drègmè kito neženkliai, todèl abi emulsijos turèjo panašų išliekamaji poveikị.

Emulsijų poveikio drègmès parametrui lyginamoji analizè. Iš pagrindinių odos diagnostikos duomenų (abiejų grupių) nustatyta, kad didesnè dehidratacijos būklè būdinga dešiniosioms rankoms, $0-15$ sąlyginių vienetų. Atlikus eksperimentinès ir kontrolinès grupių duomenų kitimą, didžiausias skirtumas matomas drègmès parametre. Eksperimentinejje grupeje tiriamosios ant dešiniosios rankos odos naudojo emulsiją su abrikosų aliejumi, paskutinę ketvirtą tyrimo savaitę nustatyta, kad drègmè pakilo, tačiau liko dehidratuotos būklès. Drègmė pakilo iki 30 sąlyginių vienetų. Nustačius išliekamajji poveikị po 1-2 savaičių drègmé buvo sumažejusi. Kontrolinès grupès tiriamosios ant dešiniuju plaštakų odos tepe emulsiją su kanapių aliejumi, paskutinę ketvirtą tyrimo savaitę nustatyta, kad drègmė pakilo iki normalaus lygio, 31-33 sąlyginių vienetų. Ištyrus išliekamajj poveiki po 1-2 savaičių drègmè buvo nepakitusi. Emulsija su kanapių aliejumi turèjo didesni poveikị kairiajai rankai, drègmès (eksperimentinès grupès) lygis išaugo iki 42 sąlyginių vienetų.

Emulsija su kanapių sėklų aliejumi geriau atstatė drègmès kieki, nepriklausomai nuo dehidratacijos lygio. Tai galejjo sąlygoti didesnis kiekis, nei abrikosų aliejuje esančių nepakeičiamujjų nesočiųjų rūgščių, dalyvaujančių lipidinio barjero formavimasi.

\section{Išvada}

1. Nustatyta, kad emulsija su kanapių ir abrikosų aliejais nevienodai atstato dehidratuotą rankų odą. Vertinant drégmès kitimą plaštakose, kurios buvo tepamos emulsija su kanapių aliejumi, atsistate iki normalaus hidratacijos kiekio, nepriklausomai nuo dehidratacijos lygio. Tuo tarpu emulsija su abrikosų aliejumi drégmès lygị atstatè tik mažiau dehidratuotoje rankų odoje.

2. Abiejų emulsijų poveikis rankų odos riebumo ir elastingumo parametrams buvo panašus, riebumas nežymiai padidèjo, elastingumas po tyrimo pasiekè maksimalią vertę.

\section{Literatūra}

1. Fowler J. Understanding the role of natural moisturizing factor in skin hydration. Pract Dermatol 2012; 9:36-40.

2. Madison KC. Barrier function of theskin:"la raison d'etre" of the epidermis. Journal of Investigative Dermatology 2003; 121(2):231-241. https://doi.org/10.1046/j.1523-1747.2003.12359.x

3. Matsui T, Amagai M. Dissecting the formation, structure and barrier function of the stratum corneum. International Immunology 2015;27(6):269-280. 
https://doi.org/10.1093/intimm/dxv013

4. Rull M, Davi C, Ca-adas E, Almi-ana N, Delgado R. Keeping skin hydrated: both inside \& out. Nutraceuticals World 2013; 28-33.

5. Foggin E, Cuddy L, Young H. Psychosocial morbidity in skin disease. British Journal of Hospital Medicine 2017;78(6): C82C86.

https://doi.org/10.12968/hmed.2017.78.6.C82

6. Sajić D, Asiniwasis R, Skotnicki-Grant S. A Look at epidermal barrier function in atopic dermatitis: physiologic lipid replacement and the role of ceramides. Skin Therapy Lett 2012;17(7):6-9.

7. Liesienè J., Kazlauskè J. Natūralios žaliavos ir bioaktyvūs priedai kosmetologijoje. KTU leidykla "Technologija", 2014;1:1122.

8. Papakonstantinou E, Roth M, Karakiulakis G. Hyaluronic acid: a key molecule in skin aging. Dermato-endocrinology 2012; 4(3): 253-258.

https://doi.org/10.4161/derm.21923

9. Targais K, Stobdan T, Yadav A, Singh SB. Extraction of apricot kernel oil in cold desert Ladakh, India. Indian Journal of Traditional Knowledge 2011;10(2):304-306.

10. Salentijn EM, Zhang Q, Amaducci S, Yang M, Trindade LM. New developments in fiber hemp (Cannabis sativa L.) breeding. Industrial Crops and Products 2015;68:32-41.

https://doi.org/10.1016/j.indcrop.2014.08.011

11. Girgih AT, He R, Malomo S, Offengenden M, Wu J, Aluko RE. Structural and functional characterization of hemp seed (Cannabis sativa L.) protein derived antioxidant and antihypertensive peptides. Journal of Functional Foods 2014; 6:384-394.

https://doi.org/10.1016/j.jff.2013.11.005

12. Ahmad A, Hadi F, Ali N. Effective phytoextraction of cadmium (Cd) with increasing concentration of total phenolics and free proline in cannabis sativa (L) plant under various treatments of fertilizers, plant growth regulators and sodium salt. International Journal of Phytoremediation 2015;17(1-6): 56-65. https://doi.org/10.1080/15226514.2013.828018

13. Callaway JC, Pate DW. Hempseed oil. In Gourmetand Health Promoting Specialty Oils 2009;1:185-213.

14. Liang J. Value addition of cold pressed hemp seed oil and oil by products through ultrasonic bleaching and heat treatment: evaluation of chlorophyll, oxidative stability and antioxidant activity 2017. (Reikia papildyti šaltini)

15. Ola DC, Budde J, Gusovius HJ. A Thermovision Assessment Method of Quality for Oily Seeds (Cannabis Sativa L.). Bulletin of the Transilvania University of Brasov. Forestry, Wood Industry, Agricultural Food Engineering. Series II. 2015; 8(2): 91-98.
16. Mikulcová V, Kašpárková V, Humpolíček P, Buňková L. Formulation, characterization and properties of hemp seed oil and its emulsions. Molecules 2017;22(5):700. https://doi.org/10.3390/molecules22050700

17. Zhou B, Wang Y, Kang J, Zhong H, Prenzler PD. The quality and volatile profile changes of Longwangmo apricot (Prunus armeniaca L.) kernel oil prepared by different oil producing processes. European Journal of Lipid Science and Technology 2016;118(2): 236-243. https://doi.org/10.1002/ejlt.201400545

18. Gupta A, Sharma PC, Tilakratne BMKS, Verma AK. (2012). Studies on physicochemical characteristics and fatty acid composition of wild apricot (Prunus armeniaca Linn.) kernel oil. Indian Journal of Natural Products and Resources 2012;3(3):366-370.

19. Małgorzata L, Dominika W, Aleksandra T, Kamila J, Adam R. Natural cold pressed oils as cosmetic products. Family Medicine \& Primary Care Review 2016;4(4): 443-447.

\section{THE EFFECT OF EMULSION BASED ON HEMP AND ABRICOT OILS FOR DEHYDRATION HAND SKIN D.Barragan Ferrer, Ž.Mickienė, J.M.Barragan Ferrer, A.Jančiauskaitė, A.Klimavičienė, S.Čapkauskienė}

Key words: dehydrated hand skin, emulsion, hemp seed oil, apricot kernel oil.

Summary

Epidermal dehydration is becoming one of the most prevalent skin problems. Elevated skin permeability is one of the most frequent side effects of this dehydration causing a deeper skin penetration of cosmetic products and other harmful substances that can lead to even more serious skin injuries/ skin problems or illness. One alternative to address this problem that has recently received fresh impetus is the use of cosmetics based on natural vegetable oils and, notably, the use of emulsions of coconut, sunflower, almond, macadamia nuts, hemp, apricot etc. These natural products have a high content of unsaturated fatty acids and other active components that can renew the skin barrier, which would ensure the sufficient amount of water and lower the consumption of cosmetic products used to reduce the dehydration. Therefore, the aim of this study is to determine the effect of dehydration on the skin of the hands using emulsions based on hemp and apricot oil. The results of the study showed that hemp oil based emulsion significantly increased the skin hydration more than the apricot oil based emulsion.

Correspondence to: diana.barragan.ferrer@go.kauko.lt

Gauta2018-09-17 